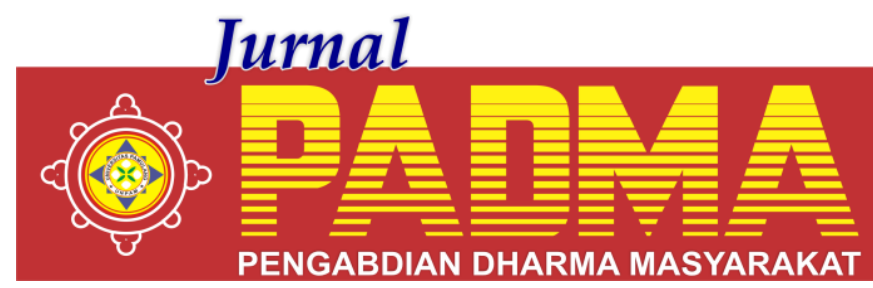

VOLUME I, NOMOR 4, OKTOBER 2021

\title{
MENINGKATKAN KEPEMIMPINAN DAN KUALITAS SUMBER DAYA MANUSIA DALAM USAHA KERIPIK PISANG PADA MEMBER GALERY UMKM RANGKASBITUNG BARAT
}

\author{
${ }^{1}$ Yosep Hendaris, ${ }^{2}$ Andika Rachman Junianto, ${ }^{3}$ Abdul Rahpin, \\ ${ }^{4}$ Santi, ${ }^{5}$ Yusnita Ika Puspitarin, ${ }^{6 *}$ Hamsinah, ${ }^{7}$ Arsid \\ Universitas Pamulang, Tangerang Selatan, Banten, Indonesia \\ *hamsinahbaharuddin12@gmail.com
}

\begin{abstract}
Abstrak
Pengabdian Kepada Masyarakat yang berjudul "Meningkatkan Kepemimpinan dan Kualitas Sumber Daya Manusia Dalam Usaha Keripik Pisang Pada Member Galery UMKM Rangkasbitung". Setiap usaha yang dilakukan selain dari tekad yang kuat dalam membentuk usaha, juga membutuhkan sikap dalam kepemimpinan untuk usahanya. Dengan jiwa kepemimpinan, maka usaha yang ditekuni akan lebih terarah dan mudah dalam menjalankan usahanya. Kepemimpinan perlu dibentuk dalam sebuah usaha. Dalam mengontrol, mengelola dan juga menentukan hasil usahanya akan lebih efisien dan efektif jika ada yang memimpin dalam usahanya tersebut. Manajemen sumber daya manusia adalah pendekatan terencana untuk mengelola orang secara efektif demi kinerja. MSDM sebagai metode mengintegrasikan dan memelihara pekerja dalam suatu organisasi sehingga organisasi dapat mencapai tujuan dan memenuhi tujuan yang didirikan. Hal ini bertujuan untuk membangun gaya manajemen yang lebih terbuka, fleksible dan peduli sehingga staf akan termotivasi, dikembangkan dan dikelola dengan cara yang dapat dan akan memberikan yang terbaik untuk mendukung misi organisasi. Kegiatan pelatihan atau konsultasi manajemen pengusaha keripik pisang sangat cocok dan relevan bagi pemeringkatan Galery UMKM, dan merupakan kegiatan bermanfaat yang dapat memperkuat kemampuan kelompok Galery UMKM untuk membentuk budaya kelompok yang lebih terbuka dan menjalankan usaha keripik pisang secara adil dan mandiri, dapat meningkatkan perekonomian masyarakat atau Kelompok Galery UMKM Karangsbitung.
\end{abstract}

Kata Kunci: Kepemimpinan, Kualitas Sumber Daya Manusia, UMKM, Usaha Keripik Pisang

\section{Abstract}

Community Service entitled "Improving Leadership and Quality of Human Resources in Banana Chips Business at Rangkasbitung UMKM Gallery Members". Every effort made apart from a strong determination in forming a business, also requires an attitude in leadership for the business. With the spirit of leadership, the business that is occupied will be more focused and easier to run its business. Leadership needs to be formed in a business. In controlling, managing and also determining the results of the business, it will be more efficient and effective if someone takes the lead in the business. Human resource management is a planned approach to managing people effectively for the sake of performance. HRM as a method of integrating and maintaining workers in an organization so that the organization can achieve its goals and meet its established goals. It aims to build a management style that is more open, flexible and caring so that staff will be motivated, developed and managed in a way that can and will give their best to support the mission of the organization. Training activities or management consultations for banana chip entrepreneurs are very suitable and relevant for rating UMKM galleries, and are useful activities that can strengthen the ability of UMKM gallery groups to form a group culture that is more open and run a banana chip business fairly and independently. Karangsbitung UMKM Gallery Group.

Keywords: Leadership, Quality of Human Resources, UMKM, Banana Chips Business

\section{PENDAHULUAN}

Buah pisang adalah buah yang dapat dijadikan sumber berbagai jenis produk olahan, misalnya keripik pisang, pisang coklat, banana cake dan sebagainya. Keripik pisang adalah produk yang sangat popular dan banyak digemari oleh kalangan masyarakat. Pada umumnya keripik pisang yang sering dijual dipasaran memiliki dua rasa yaitu rasa asin dan manis, namun pada keripik pisang juga dapat diberikan varian rasa seperti kripik pisang keju, keripik pisang vanilla, dan lain lain. Dalam memproduksi serta melakukan 
pemasarannya, keripik pisang jenis ini tentu sangat mudah dan mampu menarik perhatian konsumen sehingga mampu meningkatkan penghasilan atau omzet pelaku usaha. Biasanya setiap pelanggan membeli produk keripik pisang dalam jumlah banyak. Keripik pisang dengan bahan bakunya juga sangat mudah diperoleh, Bisa dari pedagang pisang eceran hingga pendistribusian (distributor) pisang yang sudah ke jenjang menengah dalam usahanya. Melihat banyaknya penggemar olahan keripik di masyarakat membuka peluang besar bagi mereka untuk menjadi bisnis yang menguntungkan. Potensi bisnis keripik pisang sendiri juga sangat bagus, sehingga banyak pelaku usaha UMKM yang tertarik dan memulai usaha keripik pisang untuk memanfaatkan peluang berwirausaha dibidang keripik pisang. Dengan menyediakan keripik pisang untuk memanfaatkan kegiatan komersial, omset yang sangat tinggi dapat dicapai. Permintaan masyarakat terhadap olahan keripik pisang yang terus bertambah setiap harinya dari waktu ke waktu memungkinkan peluang usaha keripik pisang menjadi sangat menjanjikan. Bisnis keripik pisang mudah dioperasikan dan tidak membutuhkan banyak modal.

Lokasi yang akan dijadikan objek penelitian dan kegiatan PKM adalah Gedung GSL (Galeri Sentral Lebak) yakni Rumah produksi dan Galery UMKM hasil dari program KOTAKU (Kota Tanpa Kumuh) dengan lokasi yang berada di Kp. Sentral, Rt.02 / Rw. 11 Rangkasbitung dengan luas $30 \mathrm{~m}$ × $20 \mathrm{~m}$. Terdapat beberapa Ruang pameran hasil usaha masyarakat, ruang kantor operasional, dan caffe yang luas yang bisa digunakan untuk kegiatan PKM, dengan fasilitas area parkiran yang luas dan view persawahan disekitar lokasi. Gedung ini biasa digunakan untuk pameran produkproduk dari masing-masing usaha untuk diperjual belikan kepada wisatawan atau warga sekitar, menjadi tempat fasilitasi penjualan untuk para member Galery UMKM, memiliki rencana sebagai tempat pusat jajanan oleh-oleh Lebak.

Beberapa warga yang tinggal disekitar kp. Sentral lebak memiliki usaha kripik pisang yang cukup populer. Hal ini dilatar belakangi oleh banyaknya warga yang memiliki kebun pisang yang hasil panennya tersebut di distribusikan ke daerah Jakarta. Namun karena banyaknya buah pisang yang tidak memenuhi standar untuk di kirim ke Jakarta maka warga tersebut berinisiatif untuk memanfaatkan pisang yang tidak dikirim dijadian kripik pisang yang memiliki nilai jual. Keripik pisang tersebut di kemas dengan varian rasa, seperti kripik pisang rasa coklat, manis, $\mathrm{BBQ}$, balado, asin, pedas, melon, aren, dan caramel. Penjualan kripik pisang ini biasanya dikirim kepasar. Bisa melalui pre order, maupun on the spot (jual beli di tempat produksi). Harga perkemasan sangat worth it. Penjualan metode online belum terlaksana atau belum adanya digitalisasi sale atau masih manual. Pengelolaan keuntungan juga belum begitu diperhatikan, dilihat dari cara kemasan produk yang masih manual dan menggunakan instink, tidak menggunakan timbangan saat proses kemasan, sehingga berat produk dalam kemasan tidak sama, karena warga menganggap jika kelebihan dalam kemasan dianggap sedekah untuk pembeli.

Kegiatan usaha kripik pisang dikelola oleh keluarga dan anggota keluarga lainnya seperti melibatkan saudara, teman, dan lainlain, sehingga system penggajian atau upah masih belum terorganisir. Jadwal serta jam kerja belum ada sehingga dapat dikatakan kegiatan usaha ini masih melibatkan saudara dalam pelaksanaannya, Karena belum terbentuknya pegawai dengan jam kerja yang ditetapkan dan dengan penggajian yang disesuaikan hal ini juga dapat dikatakan bahwa pengelolaan sumber daya manusianya masih kurang. Setiap usaha yang dilakukan selain dari tekad yang kuat dalam membentuk usaha, juga membutuhkan sikap dalam kepemimpinan untuk usahanya. Dengan jiwa kepemimpinan, maka usaha yang ditekuni akan lebih terarah dan mudah dalam menjalankan usahanya. Kepemimpinan perlu dibentuk dalam sebuah usaha. Dalam mengontrol, mengelola dan juga menentukan hasil usahanya akan lebih efisien dan efektif jika ada yang memimpin dalam usahanya tersebut. Namun karena anggota Galery UMKM didominan dengan perintis, maka struktur usaha dalam pengelolaannya masih minim dan belum terarahkan. 
Dalam konteks di atas, Galery UMKM

Lebak Banten Rangkasbitung Barat bersamaan dengan kegiatan PKM ini kami berniat untuk ikut serta berkontribusi sehigga kami dapat untuk membantu memecahkan masalah atau permasalahan yang sedang dan sedang kita hadapi dengan judul Penelitian PKM "Meningkatkan Kepemimpinan dan Kualitas Sumber Daya Manusia dalam Usaha Keripik Pisang Pada Member Galery UMKM Rangkasbitung Barat". Dari latar belakang yang dipaparkan diatas, kami menuliskan beberapa permasalahan atau perumusan masalah pada kegiatan Pengabdian Masyarakat ini seperti:

1. Bagaimana upaya dalam meningkatkan kepemimpinan pelaku usaha kripik pisang pada member Galery UMKM Rangkasbitung?

2. Bagaimana upaya dalam menciptakan Sumber daya yang berkualitas dalam usaha kripik pisang pada member Galery UMKM Rangkasbitung?

3. Bagaimana upaya meningkatkan Kepemimpinan dan kualitas sumber daya manusia dalam usaha kripik pisang pada member Galery UMKM Rangkasbitung?

\section{TINJAUAN PUSTAKA}

Program

pengembangan

kepemimpinan dapat menjadi alat utama organisasi untuk mempertahankan tim kepemimpinan yang visioner dan kuat. Karena Program peningkatan kepemimpinan sangat penting untuk keberhasilan jangka panjang organisasi juga merupakan keunggulan kompetitif. Organisasi dapat memaksimalkan dampak dan manfaat dari program pengembangan kepemimpinan pelaku usaha keripik pisang dengan menciptakan kesempatan belajar di luar Pendidikan bagi pelaku usaha keripik pisang Galery UMKM. Penelitian ini menyajikan kasus untuk kerangka kerja baru untuk program pengembangan kepemimpinan.

Meskipun subjek kepemimpinan telah diteliti secara intensif terutama pada abad terakhir, itu masih merupakan bidang yang sangat sedikit diketahui Kepemimpinan sebagian besar didefinisikan sebagai kemampuan menginspirasi dan mengesankan pengikut dengan menyediakan pelatihan kepemimpinan dengan tujuan untuk memperjuangkan terciptanya pemimpin yang berkompeten di bidang usaha keripik pisang. Menurut Firestone (2017)[1], kepemimpinan termasuk dalam posisi tertentu dan mencakup tugas dan fungsi wajib yang harus dipenuhi oleh bisnis agar dapat hidup, berkembang, dan efisien.

Berdasarkan pekerjaan dan penelitian ekstensif di bidang ini, penelitian menunjukkan bahwa pemimpin memberikan metafora yang kuat untuk kepemimpinan pelaku usaha. Dengan berhubungan baik dan dekat dengan pelaku usaha secara langsung dan secara sadar, keterampilan kepemimpinan dapat dikembangkan. Program pengembangan kepemimpinan yang dibantu secara seimbang merupakan pengalaman pembelajaran dan pengembangan kepemimpinan yang unik, membuka mata, dan mendalam mampu meningkatkan kualitas sumber daya pelaku usaha keripik pisang. Meskipun lokakarya mungkin relatif mahal menurut Koris, Alalauri, \& Pihlak (2017)[2] secara logistik sulit karena hanya dapat berlangsung di pedesaan dan perkotaan. pemimpin memotivasi para karyawan dengan menawarkan lingkungan baru. Tantangan yang tidak biasa, umpan balik langsung, dan peluang untuk mempraktikkan keterampilan yang dipelajari. Pembelajaran berbantuan pelaku usaha UMKM Rangkasbitung mungkin menjadi batas berikutnya dalam pengembangan kepemimpinan berdasarkan pengalaman. Seperti yang diklaim Hagen (2007)[3], sangat sedikit program pengembangan kepemimpinan yang dapat bersaing dengan program peningkatan kualitas kepemimpinan dalam usaha atau bisnis untuk pembelajaran langsung setiap pelaku usaha. Temuan juga konsisten dengan klaim Felton (2012, p. 200)[4] bahwa perogram kepemimpinan UMKM merupakan cara inovatif untuk membawa perspektif yang berbeda untuk program pengembangan kepemimpinan sementara mereka benarbenar efektif.

Direkomendasikan bahwa program kepemimpinan yang dibantu pelaku usaha Galery UMKM ditawarkan kepada individu yang bekerja di posisi kepemimpinan maupun pelaku usaha UMKM. Selain itu, Rumah Produksi dan Galery UMKM Rangkasbitung Barat yang menyediakan program pelatihan dan pengembangan 
kepemimpinan memasukkan lokakarya pengembangan kepemimpinan yang dibantu dengan upaya pelaku UMKM ke dalam agenda Rumah Produksi. Sangat penting untuk dicatat bahwa legitimasi program pembelajaran yang dibantu Rumah Produksi tergantung pada keberhasilan transfer pembelajaran dari lokakarya di kegiatan usaha keripik pisang dan dapat didistribusikan hasilnya kepada distributor daerah maupun luar daerah. Untuk memaksimalkan hasil dan meningkatkan lokakarya di masa depan, disarankan agar di akhir lokakarya, para peserta UMKM menilai pembelajaran mereka sendiri dan mengevaluasi lokakarya untuk memberikan umpan balik kepada fasilitator.

\section{FUNGSI DAN SIFAT PEMIMPIN}

Dari sudut pandang pengakuan resmi dari manajemen puncak, pemimpin dapat diklasifikasikan sebagai pemimpin formal dan informal. Seorang pemimpin formal adalah orang yang secara resmi ditunjuk atau dipilih untuk mengarahkan dan mengendalikan kegiatan bawahan. Dia adalah orang yang diciptakan oleh struktur formal, menikmati otoritas organisasi dan bertanggung jawab kepada mereka yang telah memilihnya secara formal. Pemimpin formal memiliki tanggung jawab dua kali lipat. Di satu sisi ia harus memenuhi tuntutan organisasi, sementara di sisi lain ia juga harus membantu, membimbing dan mengarahkan bawahannya dalam memenuhi kebutuhan dan aspirasi mereka.

Pemimpin informal tidak diakui secara formal. Mereka memperoleh otoritas dari orang-orang yang berada di bawah pengaruh mereka. Dalam organisasi mana pun kita selalu dapat menemukan beberapa orang yang memiliki rasa hormat dan yang didekati untuk membantu, membimbing, dan melindungi para pemimpin informal hanya memiliki satu tugas untuk dilakukan, yaitu membantu pengikut mereka dalam mencapai tujuan individu dan kelompok mereka. Pemimpin informal diciptakan untuk memenuhi kebutuhan yang tidak dipenuhi oleh pemimpin formal. Sebuah organisasi dapat menggunakan pemimpin informal secara efektif untuk memperkuat kepemimpinan formal.

$$
\text { Untuk mengukur keterampilan }
$$

kepemimpinan manajer di organisasi, pertimbangkan kinerja masing-masing manajer melakukan hal berikut.

1. Memberikan Bimbingan

Manajer harus dapat memberikan bimbingan dan nasihat yang berarti bagi karyawan. Jika diperlukan, manajer harus dapat menunjukkan kepada karyawan bagaimana melakukan tugas pekerjaan mereka secara lebih efisien dan efektif. Manajer juga harus dapat memberikan dukungan yang dibutuhkan karyawan untuk tumbuh dan berkembang.

2. Memotivasi Karyawan

Pemimpin yang baik memotivasi karyawan untuk bekerja keras dan memenuhi kebutuhan organisasi melalui satu atau lain cara. Beberapa pemimpin dapat menginspirasi karyawan untuk bekerja keras, sementara manajer lain dapat menyebabkan karyawan takut akan konsekuensi dari tidak bekerja keras. Kedua metode bekerja untuk mendorong motivasi dan salah satunya dapat bekerja lebih baik daripada yang lain tergantung pada gaya spesifik manajer dan budaya organisasi.

3. Memulai Aksi

Sangat penting bahwa para pemimpin memulai tindakan dengan merencanakan siapa yang akan melakukan tugas apa, kapan tugas akan diselesaikan, dan dengan cara apa tugas akan diselesaikan. Tanpa rencana yang jelas untuk menyelesaikan tujuan bisnis dan komunikasi yang baik antara manajer dan pihak terkait, sebuah organisasi akan gagal tidak peduli seberapa kuat aspek lain dari kepemimpinan manajerial. Manajer harus dapat memulai tindakan cepat untuk memanfaatkan sumber daya manusia untuk melengkapi kebutuhan bisnis.

4. Membangun Semangat dan Meningkatkan Kepuasan

Pemimpin yang baik mendorong produktivitas karyawan dengan membangun kepercayaan pada karyawan dan menciptakan lingkungan positif yang kondusif untuk produktivitas. Ketika karyawan merasa stres atau terganggu, prestasi kerja dan kepuasan kerja menderita. Ketika manajer membangun moral, itu dapat membantu meningkatkan retensi, meningkatkan kepuasan kerja 
karyawan, dan dapat berdampak baik pada laba.

5. Mengkoordinasikan Kebutuhan Karyawan dan Kebutuhan Organisasi

Salah satu hal terpenting yang harus dilakukan setiap manajer agar efektif adalah menyelaraskan kebutuhan karyawan dan kebutuhan organisasi. Bakat, minat, dan kebutuhan penjadwalan karyawan semuanya dapat menguntungkan atau merugikan organisasi, tergantung pada seberapa baik seorang manajer bekerja untuk menyelaraskan hal-hal ini dengan kebutuhan dan tujuan organisasi. Manajer terbaik akan menemukan cara untuk secara efektif menyelaraskan kebutuhan dan bakat setiap karyawan dengan tujuan organisasi.

6. Tanggung Jawab Delegasi

Adalah mungkin bagi para pemimpin untuk mendelegasikan terlalu banyak dan mungkin bagi para pemimpin untuk mendelegasikan terlalu sedikit. Pemimpin yang kuat tahu apa yang harus didelegasikan dan apa yang harus ditangani sehingga organisasi seproduktif mungkin. Pendelegasian yang memadai juga diperlukan untuk menjaga kepuasan karyawan, karena karyawan dapat mengambil keuntungan dari manajer yang mendelegasikan terlalu sedikit dan membenci manajer yang terlalu banyak mendelegasikan.

Pemimpin yang memiliki sifat-sifat tersebut di atas dan pemimpin yang tidak memiliki sifat-sifat tersebut tidaklah sama. Ini adalah konsep umum bahwa kepemimpinan adalah kombinasi dari karakteristik, kualitas, dan tindakan yang berbeda dan kualitas ini digunakan ketika berinteraksi dengan tenaga kerja (Mitonga-Monga, 2012)[5]. Seperti yang kita ketahui saat ini Kepemimpinan dunia dianggap sebagai topik yang sangat luas. Setiap individu memiliki kepribadian, pemikiran dan perilakunya masingmasing sehingga seorang pemimpin harus mempertimbangkan semua aspek ketika berhadapan dengan setiap individu.

Menurut

(Harris,

2007)[6]

kepemimpinan dapat dilihat sebagai hubungan yang digunakan oleh individu untuk membuat orang bekerja sama untuk mencapai tujuan bersama. Kinerja dapat diukur dengan mengevaluasi pada tingkat apa organisasi telah mencapai tujuan yang diinginkan. Seorang pemimpin memainkan peran kunci dalam kaitannya dengan kinerja karyawan apakah mereka individu, dalam tim atau dalam kelompok. Sikap setiap individu terhadap pemimpin suatu perilaku berbeda karena ada hubungan langsung antara perilaku pemimpin dengan kinerja pegawai. Sebagian besar Tergantung pada seorang pemimpin bahwa bagaimana dia menangani setiap karyawan di bawah kepemimpinannya. Lebih dari setengah abad penelitian menyimpulkan bahwa seorang pemimpin dapat meningkatkan kinerja individu, tim, dan kelompok menggunakan kombinasi tugas-tugas tertentu dan membangun hubungan sesuai dengan situasi.Untuk memahami dampak kepemimpinan terhadap kinerja karyawan, adalah sifat terpenting bahwa kepemimpinan memainkan peran penting dalam mengembangkan kinerja individu dalam suatu organisasi.(Obiwuru, 2011)[7].

Menganalisis kinerja karyawan adalah skenario yang kompleks karena masingmasing individu berurusan dengan perilaku pemimpin dengan caranya sendiri. Dalam setiap kinerja organisasi diukur dengan membandingkan hasil karyawan dengan tujuan dan sasaran yang ditetapkan oleh seorang pemimpin. Menurut (Klin, 2013)[8] perilaku pemimpin mempengaruhi budaya organisasi yang pada gilirannya mempengaruhi kinerja karyawan. Jelas bahwa perilaku pemimpin memiliki dampak yang signifikan terhadap organisasi pada lebih dari satu tingkat dan bahkan dapat dikatakan bahwa keberhasilan organisasi juga tergantung pada perilaku pemimpin.

Perilaku seorang pemimpin dapat dinilai dari kualitas yang dimilikinya. Tidak dapat disangkal bahwa perilaku pemimpin dianggap penting bagi karyawan, tetapi kita juga harus menyebutkan bahwa perilaku pemimpin sampai batas tertentu tergantung pada perilaku bawahannya. Di pihak karyawan, jika perilaku pemimpin mereka positif, mereka harus bekerja keras dan memberikan yang terbaik. Dalam satu atau lain cara, perilaku karyawan tergantung pada seberapa puas dia dengan pekerjaan 
dan organisasinya dan yang terakhir adalah pemimpin. Jika seorang pegawai merasa puas maka keterlibatannya dengan pekerjaannya akan tinggi, ia akan melakukan pekerjaan dengan penuh semangat dan konsentrasi. Dengan demikian, karyawan yang puas, mereka terlibat dalam pekerjaan mereka, memiliki hubungan yang energik, menyenangkan, dan efektif dengan pekerjaan mereka. Masuk akal untuk mengatakan bahwa organisasi yang karyawannya lebih terlibat dengan pekerjaan mereka lebih berhasil daripada mereka yang karyawannya tidak terlibat. Adalah logis bahwa organisasi ingin meningkatkan keterlibatan karyawan, mengingat bahwa karyawan yang terlibat bersedia untuk mengambil keuntungan penuh dari diri mereka sendiri dalam peran pekerjaan mereka dengan cara yang positif.

Pentingnya hubungan pemimpinkaryawan tidak dapat disangkal. Pentingnya dapat dilihat dengan fakta bahwa banyak penelitian sedang dilakukan tentang topik ini. Organisasi berinvestasi dalam skala tentang bagaimana mengembangkan hubungan pemimpin-karyawan yang sukses, bermanfaat dan jangka panjang yang menguntungkan organisasi. Karena hubungan antara pemimpin dan karyawan dapat membuat atau menghancurkan sebuah organisasi dengan baik, itulah mengapa hal ini sangat penting.

Dari sudut pandang pengakuan resmi dari manajemen puncak, pemimpin dapat diklasifikasikan sebagai pemimpin formal dan informal. Seorang pemimpin formal adalah orang yang secara resmi ditunjuk atau dipilih untuk mengarahkan dan mengendalikan kegiatan bawahan. Pemimpin tersebut adalah orang yang diciptakan oleh struktur formal, menikmati otoritas organisasi dan bertanggung jawab kepada mereka yang telah memilihnya secara formal. Pemimpin formal memiliki tanggung jawab dua kali lipat. Di satu sisi ia harus memenuhi tuntutan organisasi, sementara di sisi lain ia juga harus membantu, membimbing dan mengarahkan bawahannya dalam memenuhi kebutuhan dan aspirasi mereka. Pemimpin informal tidak diakui secara formal. Mereka memperoleh otoritas dari orang-orang yang berada di bawah pengaruh mereka. Dalam organisasi mana pun kita selalu dapat menemukan beberapa orang yang memiliki rasa hormat dan yang didekati untuk membantu, membimbing, dan melindungi para pemimpin informal hanya memiliki satu tugas untuk dilakukan, yaitu membantu pengikut mereka dalam mencapai tujuan individu dan kelompok mereka. Pemimpin informal diciptakan untuk memenuhi kebutuhan yang tidak dipenuhi oleh pemimpin formal. Sebuah organisasi dapat menggunakan pemimpin informal secara efektif untuk memperkuat kepemimpinan formal.

\section{KUALITAS SUMBER DAYA MANUSIA}

Sebuah studi yang dilakukan oleh (Akhtar et al., 2008)[9] menunjukkan bahwa ada kemungkinan hubungan antara manajemen sumber daya manusia (SDM) yang memadai dan peningkatan kinerja bisnis. Yaitu, pelatihan dan peluang karir internal secara positif mempengaruhi produk, dan kinerja layanan. Kinerja perusahaan berkorelasi positif dengan sistem manajemen sumber daya manusia berkinerja tinggi. Sistem manajemen sumber daya manusia terkait erat dengan strategi bisnis, sehingga secara positif mempengaruhi kinerja bisnis. Namun, (Apospori et al., 2008)[10] berpendapat bahwa manajemen sumber daya manusia mungkin memiliki pengaruh yang berbeda pada kinerja perusahaan di lingkungan yang berbeda (lokasi geografis, pesaing, pasar, dan lain-lain). Pengaruh sistem manajemen sumber daya manusia tergantung pada berbagai faktor yang berpengaruh, dan tidak selalu pasti dengan cara apa tindakan sumber daya manusia tertentu akan mempengaruhi kinerja bisnis. Lalai untuk berasumsi bahwa praktik manajemen sumber daya manusia secara definitif dapat meningkatkan kinerja perusahaan (Wall \& Wood, 2016)[11].

Isu pengembangan personel terpadu sebagai implementasi inisiatif manajemen dalam praktik perusahaan sangat penting. Mereka terutama diekspresikan dalam kondisi modern perkembangan hubungan ekonomi, ditandai dengan meningkatnya pengaruh proses globalisasi di semua bidang kegiatan perusahaan, meningkatnya peran tanggung jawab sosial manajemen dan pembaruan pendekatan manajemen yang 
konstan. Pendekatan dan alat manajemen personalia yang ada ditujukan untuk memecahkan masalah saat ini. Dalam kondisi seperti itu, urgensi tugas membentuk strategi personel yang masuk akal dan efektif semakin meningkat. Ini memberikan fokus manajemen untuk menciptakan keunggulan kompetitif yang berkelanjutan dan mencapai efektivitas manajemen jangka panjang. Semua kontradiksi perlu memperkuat peran faktor-faktor pengaruh tertentu dan pengungkit personel untuk menghilangkan atau mengurangi manifestasi kontradiksi ini. Untuk mencapai hasil yang optimal, perlu untuk terus memperhitungkan kompleks tindakan semua faktor internal dan eksternal yang menentukan dinamika pertumbuhan perusahaan.

Manajemen sumber daya manusia di zaman kita dianggap sebagai salah satu fungsi organisasi perusahaan yang paling penting dan sensitif. Ini menyangkut faktor manusia, di mana perusahaan dapat mencapai keunggulan kompetitif. Hal ini adalah sumber daya paling berharga yang dibutuhkan oleh manajer di semua bidang dan fase pekerjaan. Selain itu, siapa pun yang peduli dengan kesuksesan organisasi bisnis menemukan bahwa kesuksesan tidak bergantung pada penggunaan teknologi canggih dan bukan pada diversifikasi sumber pembiayaan mereka. Organisasi bisnis bukan hanya seperangkat fasilitas atau kebijakan dan undang-undang, tetapi sekelompok orang yang memiliki hubungan umum dan berinteraksi satu sama lain untuk melakukan tugas-tugas dasar, dan fungsi membantu mereka untuk mencapai tujuan dan sasaran organisasi. Manajemen strategis sumber daya manusia mencakup studi aktif sumber daya manusia, analisis dan menghubungkan dengan tujuan dan strategi perusahaan. Dengan demikian, faktor manusia menjadi salah satu sarana untuk mencapai keunggulan kompetitif dan meningkatkan kondisi pasar perusahaan dan hasil bisnisnya (Shehadeh \& Mansour, 2019)[12].

Para peneliti model penilaian fleksibilitas strategis menguraikan faktorfaktor berikut: sensitivitas strategis, keterikatan kolektif, pergantian sumber daya, kesatuan kepemimpinan, manajemen perubahan, penggunaan teknologi informasi, pengembangan perspektif strategis, pemahaman peluang kunci, pilihan tujuan strategis, strategi perencanaan, pengetahuan pelanggan, tanggung jawab dan tindakan bersama (Asil, 2019)[13]. Kebutuhan untuk membentuk dan menerapkan sistem manajemen yang efektif merupakan isu kunci; oleh karena itu, perhatian khusus diberikan pada pengenalan prinsip dan metode manajemen umum, meningkatkan manajemen personalia, dan mengambil langkah-langkah untuk memastikan operasi yang stabil dari perusahaan-perusahaan yang berusaha untuk memperkuat posisi mereka di lingkungan pasar yang terus berubah.

Ekonomi menciptakan kondisi untuk pembangunan manusia, untuk meningkatkan tingkat dan kualitas hidup, dan manusia adalah sumber daya aktif yang penting untuk pertumbuhan ekonomi. Faktor eksternal yang mempengaruhi pengembangan sumber daya manusia, peningkatan kualitas dan efisiensi penggunaan, misalnya, perubahan lingkungan makro dan persaingan, perkembangan ekonomi baru dan masyarakat informasi, proses globalisasi, peningkatan tanggung jawab sosial bisnis, arah inovatif pengembangan perusahaan, intelektualisasi produksi dan proses bisnis, peningkatan peran pendidikan dan pelatihan personel yang berkelanjutan, masalah perlindungan sosial karyawan dan sejenisnya. Saat menganalisis personel, sumber daya manusia, potensi manusia, perusahaan menggunakan serangkaian indikator, misalnya, potensi tenaga kerja, remunerasi tenaga kerja, pembayaran dan tunjangan sosial, pelatihan kejuruan dan pelatihan ulang karyawan, kondisi kerja, iklim moral dan psikologis dalam tim, personel pergerakan, dll. Sebagai indikator kondisi komponen potensi personel yang paling sering menjadi: pergantian staf, kompetensi karyawan, kepuasan dengan kondisi kerja, dan sejenisnya. Indikator pelaksanaan komponen potensi tenaga kerja adalah produktivitas tenaga kerja.

Peneliti percaya bahwa karyawan perlu mengetahui kisaran kebutuhan mereka, tingkat kepuasan kerja mereka, motif, faktor dominan yang secara positif dan negatif mempengaruhi sikap kreatif mereka terhadap kinerja tugas, inisiatif, pengembangan diri, individu dan 
pertumbuhan profesional. Ketika mempelajari masalah manajemen strategis sumber daya manusia, spesialis mengutip strategi yang berbeda (Shehadeh \& Mansour, 2019)[13], misalnya, strategi manajemen personalia fungsional, strategi pembentukan sumber daya manusia, strategi untuk menganalisis dan merancang fungsi, strategi untuk merencanakan sumber daya manusia. sumber daya, strategi ketenagakerjaan, strategi pelatihan dan pengembangan, strategi evaluasi efektivitas sumber daya manusia, strategi remunerasi.

USAHA MIKRO KECIL MENENGAH (UMKM)

UMKM adalah program pemerintah yang dilakukan perorangan, keluarga, dan usaha kecil yang mendorong pembangunan ekonomi Indonesia. M. Kwartono Adi (2019)[14] menjelaskan definisi UMKM yaitu H. Dihitung berdasarkan laba tahunan, perusahaan yang laba atau labanya kurang dari 200 juta rupiah. Jika suatu perusahaan atau badan usaha memenuhi standar untuk usaha mikro, maka dapat disebut UMKM. Menurut Peraturan yang mengatur tentang usaha kecil, menengah, dan mikro diklasifikasikan menurut jenis usahanya masing-masing, yaitu usaha mikro dan usaha kecil dan menengah. Meskipun usaha mikro, kecil dan menengah biasanya didefinisikan sebagai satu kesatuan, ini merupakan akronim untuk tiga jenis usaha yang berbeda. Ketiga jenis perusahaan tersebut adalah:

1. Micro Bussiness merupakan usaha yang dijalankan oleh perorangan atau keluarga. Perusahaan dengan pendapatan bersih tahunannya tidak melebihi Rp50 juta adalah usaha mikro. Pengelolaan keuangan Wechat biasanya juga dipadukan dengan pengelolaan keuangan pribadi.

2. Usaha kecil adalah perusahaan yang laba bersih tahunannya antara 50-300 juta rupiah. Usaha ini terdiri dari usaha yang formal maupun informal, seperti: Industri produk fasion yang berfokus pada tekstil rumah tangga. Hal ini juga dapat berlaku pada usaha kecil atau institusi, seperti toko kecil dan restoran.

3. Usaha Menengah merupakan usaha yang dalam pengelolaannya sudah menggunakan basis atau system akuntansi yang sudah lengkap juga terstruktur. Perusahaan menengah memiliki sistem manajemen yang sudah lengkap, terlepas dana atau modal pribadi, direktur dan presiden. Jika sebuah perusahaan memiliki lebih dari satu usaha kecil dengan pendapatan tahunan lebih dari 300 juta yuan, dapat dikatakan cukup memuaskan. Selain dokumen hukum lainnya, perusahaan menengah juga bertanggung jawab untuk mengelola kekayaan NPWP agar usahanya dapat diakui oleh pemerintah dan negara.

Sebagai badan usaha, usaha kecil, menengah dan mikro memiliki beberapa ciri yang jelas. Contoh:

a. Sewaktu-waktu jenis barang dapat berubah sesuai dengan ketentuan pelaku usaha.

b. Adanya bentuk usaha tetap yang dapat direlokasi jika diperlukan.

c. Tidak ada aplikasi manajemen yang lengkap. Bahkan, pengelolaan keuangan mereka seringkali disamakan dengan pengelolaan uang milik sendiri atau modal pribadi.

d. Jiwa wira usaha yang dimiliki sumberdaya manusia belum begitu sempurna sehingga perlu adanya latihan peningkatan kompetensi secara berkala.

e. Sebagian besar peserta UMKM tidak dapat menggunakan layanan perbankan, meskipun sebagian besar peserta dapat menggunakan layanan bukan bank (nonBank).

f. Sebagian besar pelaku usaha berjalan illegal atau belum memiliki izin resmi dari pemerintah setempat atau undangundang lainnya, seperti Nomor Pokok Wajib Pajak.

Peran dan peran usaha kecil, menengah dan mikro dalam lingkungan ekonomi.

1. Menciptakan lapangan kerja

Kesempatan kerja baru akan meluas sehingga mampu mengurang tingkat pengangguran dilingkungan masyarakat sekitar. Diimbang dengan perusahaan terkemuka lainnya, perusahaan kecil, menengah dan sangat kecil dapat beroperasi dengan persyaratan pekerjaan yang lebih rendah dan dapat diiklankan oleh orang-orang dengan pendidikan rata-rata lebih rendah atau tidak memiliki kualifikasi khusus. 
Oleh karena itu, bisnis ini bisa menjadi jalan bagi masyarakat untuk mendapatkan penghasilan tanpa harus melepaskan aktivitas sehari-hari yang tidak bisa ditinggalkan. Misalnya, ibu rumah tangga dapat bergabung dengan usaha kecil dan mikro dan menjadi pengrajin dan pekerja di industri katering.

2. Memajukan perekonomian yang lebih adil

Usaha kecil, menengah dan mikro merupakan cara suatu negara untuk mencapai perkembangan perekonomian yang lebih adil yang mampu menyejahterakan masyarakan yang lebih awam dalam berwirausaha. Bahkan, upaya ini juga telah meningkatkan dan memperbaiki kondisi ekonomi kota-kota kecil dan desa-desa. Masyarakat juga dapat membeli berbagai produk dan jasa di dekat pemukiman mereka tanpa perlu masuk ke ibukota atau pusat kota. Dapat digambarkan bahwa usaha kecil, menengah dan mikro gagal berkembang, penduduk pedesaan harus pergi ke pusat distributor dan pasar-pasar pada kota besar setiap hari untuk mencapai pemenuhan kebutuhan hidup dasar mereka. Dalam hal ini, situasi ekonomi di pedesaan pasti akan jauh lebih buruk daripada di kota.

3. Devisa suatu negara meningkat

Perekonomian negara Indonesia dapat dilihat dari faktor tertentu seperi Devisa adalah salah satunya. Jika memiliki nilai yang tinggi, maka dapat dikatakan perekonomian negara tersebut berada pada posisi maju dan dapat disebut sebagai negara kaya. Negara secara tidak langsung mendorong pertumbuhan devisa dengan meningkatkan stok dan pengelolaan usaha kecil, menengah dan mikro. Contoh paling sederhana adalah usaha besar, kecil, menengah dan mikro, yang dapat menghasilkan produk berkualitas tinggi untuk menarik perhatian konsumen luar negeri. Jika Anda secara teratur mengekspor barang ke konsumen luar negeri, negara akan menghasilkan pendapatan tambahan. Selain itu, kegiatan perdagangan internasional saat ini dapat dengan mudah dilakukan secara online melalui Internet.
4. Menghidupkan kembali perekonomian pada masa krisis

Kemampuan usaha kecil, menengah dan mikro untuk merevitalisasi perekonomian pada masa krisis nasional sudah jelas terlihat. Pada tahun 1997, berkat perkembangan usaha kecil, menengah dan mikro, krisis mata uang Indonesia berhasil diatasi. Oleh karena itu, meskipun krisis mata uang, masyarakat Indonesia dapat lebih mudah memenuhi kebutuhan dasar mereka. Pada masa Pandemik Covid 19 ini, Jika ada saran untuk tidak keluar rumah, usaha kecil menengah dan mikro bisa beralih penawaran produknya melalui digital marketing atau pemasaran berbasis online untuk sekaligus pemenuhan kebutuhan masyarakat. Dengan cara ini, perekonomian akan terus berlanjut dan berangsur pulih.

5. Pemenuhan kebutuhan masyarakat secara rinci

Kegiatan usaha ini dijalankan oleh masyarakat kecil yang mengetahui berbagai jenis kebutuhan masyarakat sekitar. Produk-produk inovatif yang dihasilkan seringkali dapat memenuhi kebutuhan masyarakat. Selain itu, usaha kecil, menengah dan mikro harus membeli berbagai bahan baku untuk di produksi dari produsen lokal, Hal ini tentunya dapat membawa manfaat yang lebih bagi masyarakat sekitar baik produsen maupun konsumen yang juga menjadi pembeli produk hasil dari kegiatan pelaku UMKM lainnya, dan mampu meningkatkan atau menambah omzet ekonomi dengan lebih cepat.

Usaha kecil, menengah dan mikro memiliki modal kecil dan dapat menjadi motor penggerak penting bagi perekonomian nasional. Usaha kecil, menengah dan mikro berperan penting terhadap kemajuan dan perkembangan perekonomian dan dapat memulai usaha dengan modal yang lebih sedikit. Selain itu, karena sifatnya yang fleksibel, bisnis ini juga dapat dijadikan sebagai alternatif penghasilan tambahan dalam situasi sulit. Jika dikelola dengan baik, pelanggan, konsumen, dan pemerintah semuanya dapat memperoleh manfaat dari usaha kecil, menengah dan mikro. 


\section{METODE}

Kegiatan ini menerapkan mekanisme perwujudan dari aktivitas pengabdian kepada masyarakat yang diselenggarakan dalam beberapa tahapan yaitu:

1. Tahapan awal yang terdiri dari:

a. Survei lokasi Rumah Produksi dan Galery UMKM yang beralamatkan di Rangkasbitung Barat, Lebak-Provinsi Banten.

b. Observasi Langsung ke kantor Rumah Produksi dan Galery UMKM dan rumah penduduk anggota UMKM sehingga mendapatkan informasi yang detail mengenai objek yang dibutuhkan.

c. Melaksanakan rapat koordinasi tim panitia dan kelas secara berkala perihal pendistribusian tanggung jawab bagi mahasiswa yang terlibat dalam struktur kepanitiaan, menyusun agenda realisasi kegiatan, hingga menyusun ulasan dan laporan kegiatan. d. Menyusun proposal realisasi kegiatan PKM pada UMKM galeri untuk diajukan ke pihak kampus dan pengurus Galery UMKM.

e. Melengkapi administrasi surat dalam rangka persiapan PKM.

f. Mengumpulkan dan menyiapkan bahan dan materi yang akan disampaikan ke peserta PKM.

g. Bimbingan secara intensif dengan dosen pembimbing dalam rangka persiapan PKM di Rangkasbitung dalam kegiatan bimbingan tersebut dosen memberikan bekal pengetahuan bagi mahasiswa terkait materi teknis dan non teknis dalam persiapan acara PKM. Adapun bimbingan dilakukan secara tatap muka di kampus Victor dan secara media online.

2. Tahap pelaksanaan PKM dengan acara inti berupa penyampaian materi PKM kepada anggota masyarakat atau peserta PKM yang terlibat dalam Galery UMKM melalui:

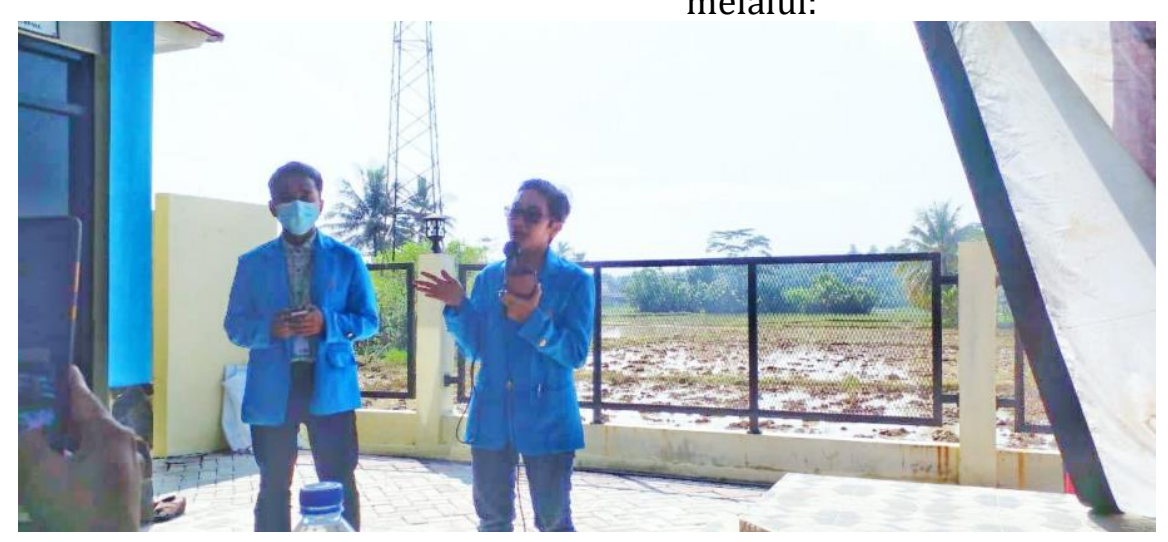

Gambar 1. Sharing Tentang Materi Penyuluhan

a. Sosialisasi materi terkait Kepemimpinan dan Kualitas Sumber daya Manusia dalam usaha keripik pisang.

b. Membuka sesi tanya jawab dan diskusi terkait materi yang disampaikan yaitu tentang kepemimpinan dan dan kualitas sumber daya manusia.

c. Praktek bersama dan pelatihan dalam kelompok untuk mempraktekkan secara langsung simulasi menciptakan kripik pisang dengan rasa baru dan merek yang unik agar dapat diterapkan UMKM dan diterima oleh masyarakat luas.

d. Sesi pendalaman materi pada sesi ini narasumber memberikan pertanyaan kepada para peserta yaitu anggota galeri UMKM terkait materi yang sudah dibahas agar acara semakin hidup dan panitia menyiapkan hadiah bagi peserta yang aktif

e. Melakukan bimbingan dan pelatihan secara berkelanjutan berdasarkan solusi atas permasalahan pada UMKM galeri komunikasi Intens dan diskusi yang dinamis dilakukan meskipun acara PKM sudah berakhir di mana anggota UMKM galeri dapat menghubungi mahasiswa peserta PKM terkait permasalahan yang terjadi dalam proses peningkatan kepemimpinan dan kualitas sumber daya manusia.

3. Tahap pelaporan dalam salah satu dokumen kontrak dengan pihak kampus maka mahasiswa berkewajiban untuk melaksanakan pengabdian kepada masyarakat dan menyelesaikan 
laporan pelaksanaan PKM sebelum batas waktu yang telah ditetapkan berakhir pada tahap ini penyusunan laporan kegiatan PKM oleh mahasiswa pascasarjana sebagai wujud pertanggungjawaban mahasiswa kepada pihak kampus selaku pemberi tugas.

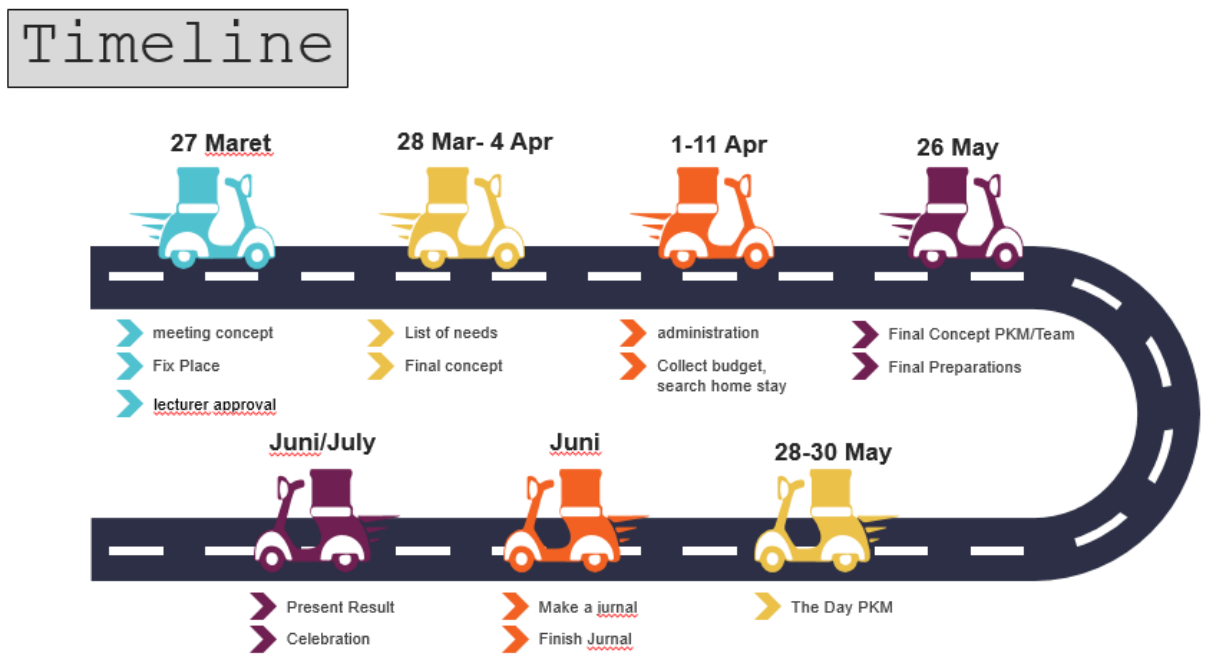

Gambar 2. Timeline Kegiatan PKM

\section{SOLUSI PERMASALAHAN}

Beberapa tindakan dalam upaya merealisasikan pemecahan masalah tersebut dapat dilihat pada kegiatan pelaksanaan pemberian materi yang disampaikan semua anggota kelompok, memberikan arahan dan pengetahuan guna meningkatkan kemampuan para perintis pada member Galery UMKM. Memberikan kegiatan tanya jawab tentang materi untuk mengetahui keaktifan dan daya ingat, juga memberikan games yang menyenangkan agar tercapainya target untuk meningkatkan pengetahuan perintis. Hal mendasar yang ditawarkan untuk ikut memecahkan masalah adalah melalui kegiatan penyuluhan dan pelatihan kepada pengurus Galery UMKM dengan anggota yang tergabung dalam Galery UMKM dengan bidang usaha keripik pisang yang dikemas dengan nama kegiatan "Meningkatkan Kepemimpinan dan Kualitas
Sumber Daya Manusia Dalam Usaha Keripik Pisang Pada Member Galery UMKM Rangkasbitung Barat.

\section{HASIL DAN PEMBAHASAN}

UMKM adalah usaha yang dijalankan oleh perorangan, keluarga atau usaha kecil. Usaha kecil, menengah dan mikro biasanya diklasifikasikan menurut batas penjualan tahunan, jumlah aset atau jumlah karyawan. Sedangkan perusahaan yang tidak termasuk UMKM tergolong perusahaan besar, yaitu perusahaan manufaktur adalah perusahaan patungan yang dibentuk oleh perusahaan yang kekayaan bersih atau penjualan tahunannya lebih tinggi dari perusahaan menengah termasuk BUMN atau swasta milik negara, Perusahaan, Dan bisnis internasional. Terlibat dalam kegiatan ekonomi di Indonesia.

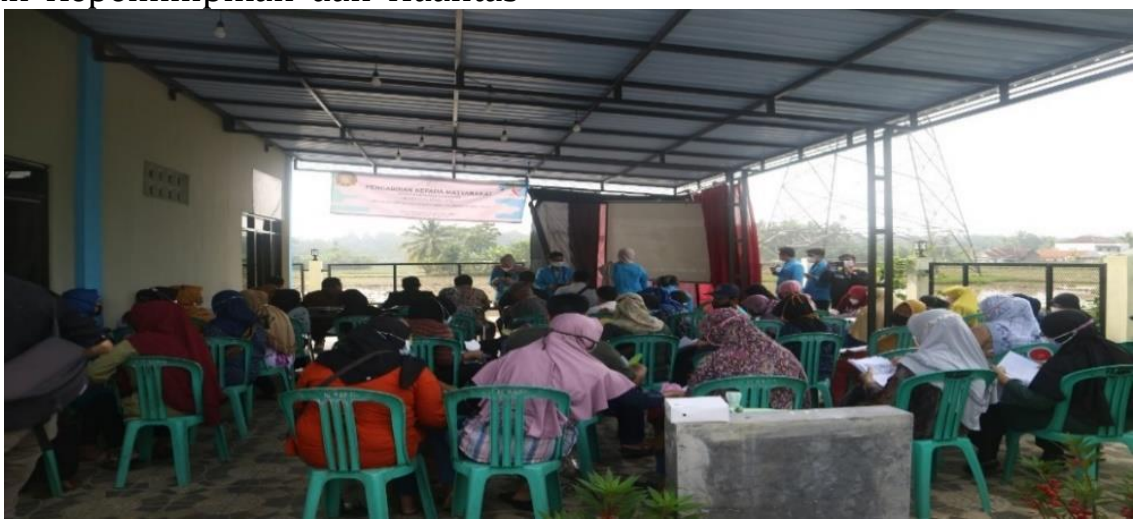

Gambar 3. Kegiatan Pelatihan Inovasi Produk 
Di Indonesia, definisi UMKM diatur oleh Undang-Undang Republik Indonesia No. 20 Tahun 2008 tentang UMKM. 1) Pasal 1 undang-undang tersebut menetapkan bahwa usaha mikro adalah usaha produksi yang dimiliki oleh orang perseorangan dan/atau badan usaha perseorangan yang memenuhi standar usaha mikro yang ditentukan oleh undang-undang. 2) Usaha kecil adalah usaha ekonomi produktif mandiri yang dijalankan oleh suatu unit usaha yang langsung atau tidak langsung dimiliki atau dikuasai oleh orang perseorangan atau bukan anak perusahaan atau bagian dari perusahaan menengah atau besar. Mematuhi standar bisnis kecil dalam pengertian hukum. Saat ini, usaha mikro adalah usaha komersial produktif yang berdiri sendiri yang dijalankan oleh orang perseorangan atau perusahaan, bukan anak perusahaan atau cabang perusahaan yang langsung atau tidak langsung dimiliki, dikuasai, atau sebagian dimiliki oleh perusahaan mikro, kecil, atau besar. berhak. perusahaan. Pengertian hukum mikro. Menurut Tambunan (2011:27)[15], UMKM adalah unit usaha produktif mandiri yang dijalankan oleh perorangan atau perusahaan dari berbagai sektor ekonomi. Pada dasarnya perbedaan antara usaha mikro (UMI), usaha kecil (UK), usaha menengah (UM) dan usaha besar (UB) biasanya didasarkan pada aset awal (tidak termasuk tanah dan bangunan), omset tahunan rata-rata atau jumlah karyawan.

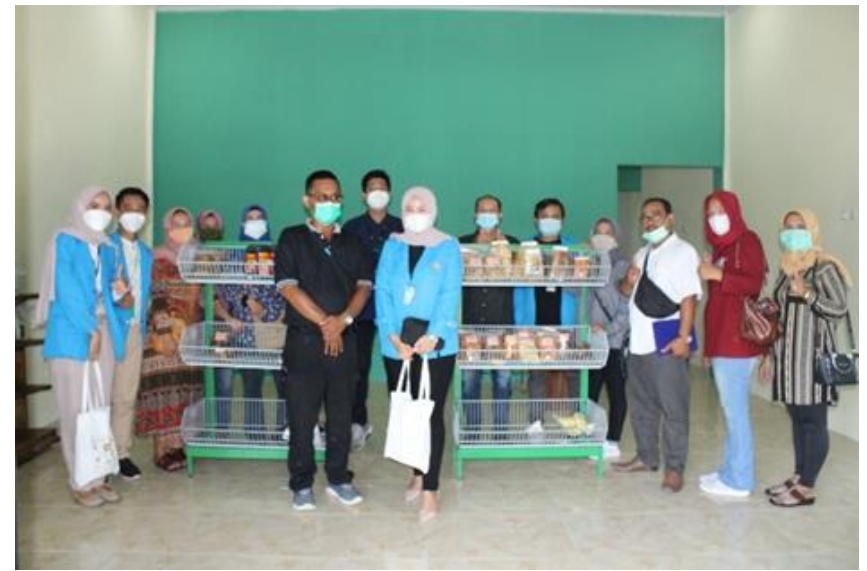

Gambar 4. Dokumentasi Produk

Bisnis keripik pisang memang bisa dikatakan salah satu bisnis yang paling menjanjikan. Bisnis keripik pisang disana sangat digemari oleh semua kalangan. Selain itu, keripik pisang juga sangat mudah diolah, dan bahan baku yang Anda butuhkan tersedia dimana-mana. Namun, jika didukung dengan peralatan berkualitas tinggi yang cukup, pengolahan keripik pisang akan menjadi lebih mudah, sehingga kinerja pengolahan lebih hemat energi dan hemat waktu. Bisnis keripik pisang kini bisa dijadikan sebagai lahan bisnis untuk mendapatkan cash register yang cukup tinggi. Berbagai persyaratan yang perlu disiapkan antara lain peralatan dan bahan baku. Peralatan yang digunakan untuk membuat keripik pisang antara lain pisau, talenan, ember, wadah dan berbagai peralatan lainnya. Bahan baku yang perlu disiapkan adalah pisang, garam halus, minyak goreng, dll.
Dalam menjalankan usaha keripik pisang, penting juga untuk menentukan lokasi usaha keripik pisang sendiri. Karena hal ini akan mempengaruhi keberhasilan usaha keripik pisang yang mereka ikuti. Agar bisnis keripik pisang dapat berjalan dengan baik dan mudah diketahui oleh semua orang, maka perlu ditentukan lokasi yang tepat untuk menjual keripik pisang. Sebenarnya ada banyak cara untuk mengiklankan bisnis keripik pisang, baik langsung ke konsumen maupun dari mulut ke mulut.

Jika Anda menjalankan bisnis keripik pisang, Anda memerlukan bantuan mesin. Salah satu mesin yang dapat digunakan untuk memaksimalkan usaha keripik pisang adalah mesin pencacah pisang. Saat memotong pisang, penting juga untuk menggunakan perajang pisang. Dengan menggunakan banana chopper, proses pencacahan pisang dapat dilakukan dengan sederhana, cepat dan efektif. Ini juga menghasilkan keripik pisang yang cocok 
untuk menghasilkan keripik pisang yang lebih berkualitas. Proses pencacahan pisang menggunakan perajang pisang membuat proses lebih nyaman karena mesinnya otomatis.

Kepemimpinan atau kemampuan kepemimpinan sangat penting bagi pengusaha untuk menjalankan bisnis. Tanpa kepemimpinan atau keterampilan kepemimpinan, tidak akan ada kesuksesan. Seringkali kita menemukan bahwa perusahaan orang lain sebenarnya dijalankan oleh orang lain karena dianggap lebih percaya diri dan lebih berkualitas. Pemimpin yang sukses adalah pemimpin yang mampu memimpin dalam berbagai kondisi. Menurut Kurt Lewin (2012)[16], ada tiga gaya kepemimpinan utama: otoriter, demokratis, dan laissez-faire. Masing-masing memiliki kelebihan dan kekurangannya sendiri dan dapat diterapkan pada kondisi yang berbeda.

1. Gaya Otokratis

Seorang pemimpin dengan gaya kepemimpinan otokratis adalah gaya kepemimpinan sepihak. Pemimpin otoriter akan membimbing orang lain untuk mewujudkan visinya.

2. Gaya Demokratis

Pemimpin yang demokratis adalah pemimpin yang memberikan ruang kepada bawahannya untuk menyampaikan pendapat. Meskipun gaya kepemimpinan demokratis lebih sering digunakan, mereka tidak cocok untuk membuat keputusan penting. Menyatukan pendapat yang berbeda itu mudah, tetapi butuh waktu lama.

3. Gaya Laissez-faire

Laissez-faire adalah gaya kepemimpinan yang cenderung pasif. Manajer dengan gaya kepemimpinan ini memungkinkan orang lain untuk membuat keputusan.

4. Kemudian dijelaskan oleh Rahardjo (2010:18)[17], yang menjelaskan konsep kualitas sumber daya manusia, yaitu: "Kualitas sumber daya manusia tidak hanya tergantung pada kemampuan atau kekuatan fisik, tetapi juga pada pendidikan atau tingkat pendidikan. Pengalaman atau kedewasaan dan adopsi Menurut Selo Sumarjan (2011: 43)[18], kualitas sumber daya manusia di
Indonesia yang kita inginkan didasarkan pada kebugaran jasmani (kesehatan, kekuatan fisik, kemampuan dan ketangguhan) dan kualitas non fisik (kemandirian, ketekunan, kejujuran dan moral).

\section{PENUTUP KESIMPULAN}

Selain tekad yang kuat untuk memulai bisnis, setiap upaya juga membutuhkan sikap terhadap operasi bisnis. Dengan jiwa kepemimpinan, kepegawaian perusahaan menjadi lebih fokus dan lebih mudah dioperasikan. Kepemimpinan harus dibentuk dalam perusahaan. Dalam hal pengendalian, pengelolaan, dan penentuan hasil bisnis, ketika seseorang memimpin bisnis menjadi lebih efisien dan efektif. Namun karena para anggota Galery UMKM sebagian besar merupakan pionir, maka struktur usaha yang mereka kelola masih sangat kecil dan tidak terarah. Dalam rangka melaksanakan ketiga undang-undang pendidikan tinggi di bidang pendidikan, penelitian, dan pengabdian, Universitas Bamulan membuka diri dan terus berpartisipasi dan memajukan berbagai kegiatan yang berkaitan dengan pengembangan ilmu pengetahuan, kelembagaan, teknologi, dan seni. Universitas Palmerang telah menjalin banyak jaringan dengan berbagai institusi seperti instansi pemerintah pusat, pemerintah provinsi, pemerintah kabupaten, dunia usaha, swasta dan masyarakat sekitar.

$$
\text { Rumah Produksi UMKM }
$$

Rangkasbitung adalah kumpulan organisasi masyarakat, sebagai kumpulan pelaku ekonomi UMKM, mereka terhubung melalui perasaan sukarela untuk membentuk kelompok masyarakat berdasarkan ikatan yang bersatu, yaitu ada visi atau tujuan, dan kepentingan yang sama perlu untuk menggabungkan Tujuan ini dicapai sebagai tujuan bersama. Kelompok ini muncul dari kebutuhan dan kesadaran komunitas yang dikelola itu sendiri, dan berkembang dengan berbagai media atau sumber daya manusia dan sumber daya lain yang tersedia dalam kerangka komunitas untuk menciptakan tujuan bersama, yang menjadi prinsip yang akan memperkuat komunitas secara tepat. Kegiatan pelatihan atau konsultasi manajemen pengusaha keripik pisang sangat 
cocok dan relevan bagi pemeringkatan Galery UMKM, dan merupakan kegiatan bermanfaat yang dapat memperkuat kemampuan kelompok Galery UMKM untuk membentuk budaya kelompok yang lebih terbuka dan menjalankan usaha keripik pisang secara adil dan mandiri nilai dapat meningkatkan perekonomian masyarakat atau Kelompok Galery UMKM Karangsbitung. Kegiatan Pengabdian Masyarakat (PKM) ini merupakan program yang dijalankan oleh tim pengabdian, yang pertama adalah mengunjungi lokasi Galery UMKM dan mewawancarai direksi dan beberapa anggota Galery UMKM melalui observasi fisik secara langsung selama usaha keripik pisang yang dijalankannya.

\section{SARAN}

Saran penulis untuk pembaca agar lebih mengembangkan kemampuan untuk memimpin dan terus meningkatkan kualitas diri dalam merintis usaha, baik dari segi metode pembelajaran yang di gunakan ataupun media pembelajaran saat praktek usahanya. Jika anda seorang perintis usaha menengah, maka sebaiknya untuk mencoba melakukan hal-hal baru seperti membuat produk dengan inovasi baru baik dari segi rasa maupun jenis produknya. Dengan adanya pengembangan inovasi dari segi produk, diharapkan perintis mampu mengembangkan usahanya kejenjang yang lebih tinggi serta dapat meluaskan usahanya sehingga dapat didistribusikan hingga luar kota atau bahkan meluas sampai mengglobal.

\section{DAFTAR PUSTAKA}

Achmad, Ruky. 2015. Kualitas Sumber Daya Manusia. Jakarta: PT Gramedia Pustaka Utama.

Adair, John, 2008. Kepemimpinan yang memotivasi. Jakarta: PT. Gramedia Pustaka Utama.

Arikunto, Suharsimi. 2006. Prosedur Penelitian Suatu Pendekatan Praktik. Jakarta: Rineka Cipta.

Mangkuprawiro, Sjafri, 2002, Manajemen Sumber Daya Manusia Strategik, Cetakan Pertama, PT. Gramedia, Jakarta.

Pratiwi, Ami. 2010. Pengaruh Kualitas Sumber Daya Manusia Dan Motivasi Kerja Terhadap Produktivotas Kerja Karyawan Di PT Djitoe Tobacco Surakarta. Surakarta: Universitas Muhammadiyah Surakarta.

Rahmat HM. PKM Magister Manajemen UNPAM Berikan Pembinaan UMKM Rangkasbitung Hadapi Pandemi. https://suarapemerintah.id/2021/06/ pkm-magister-manajemen-unpamberikan-pembinaan-umkmrangkasbitung-hadapi-pandemi. html diakses pada 08 Juni 2021 Pukul 08.13 WIB. 